\title{
Implikasi Pendidikan Kristen dalam Keluarga Menurut Efesus 6: 1-4 Pada Masa Pandemi Covid-19
}

\author{
Reynhard Malau \\ Institut Agama Kristen Negeri Palangkaraya \\ reynhardmalau@gmail.com
}

\begin{abstract}
This study aims to see the implications of Christian education in families according to the text of Ephesians 6: 1-4 during the Covid-19 pandemic. In connection with the biblical text as an object, this research is classified as a type of descriptive research using an interpretive paradigm, more precisely called the interpretive descriptive method, by interpreting the text of Ephesians 6: 1-4, this method aims to build a theoretical framework that underlies interpretation, as well as describes the results of the analysis on the basis of findings which are clarified by theory. The results of this study are the implications of Christian education in the family according to the text of Ephesians 6: 1-4 during the Covid-19 pandemic, namely: improving the quality of the role of parents in the spiritual growth of children, as described in the exegesis of Ephesians 6: 1-4, growth. Spiritual children are the responsibility of parents, a child will respect their parents on the basis of fear of God, direction and education from parents which are also based on fear of God.
\end{abstract}

Keywords: christian education; family; covid-19

\begin{abstract}
Abstrak
Penelitian ini bertujuan untuk mengetahui bagaimana implikasi pendidikan Kristen dalam keluarga menurut teks Efesus 6: 1-4 pada masa pandemi Covid-19. Berhubungan dengan teks Alkitab sebagai objek, maka penelitian ini tergolong dalam jenis penelitian deskriptif dengan menggunakan paradigma interpretatif, lebih tepatnya disebut metode deskriptif interpretatif, dengan melakukan tafsir terhadap teks Efesus 6: 1-4, metode ini bertujuan membangun kerangka teori yang melandasi penafsiran, serta membeberkan hasil analisis atas dasar temuan yang diklarifikasi dengan teori. Hasil penelitian ini adalah implikasi pendidikan Kristen dalam keluarga menurut teks Efesus 6: 1-4 pada masa pandemi Covid-19, yaitu: meningkatkan kualitas peran orangtua terhadap pertumbuhan rohani anak, seperti apa yang telah dijabarkan pada eksegesis Efesus 6: 1-4, pertumbuhan rohani anak sudah merupakan tanggung jawab dari orangtua, seorang anak akan menghormati orangtuanya atas dasar rasa takut akan Tuhan karena arahan dan pendidikan dari orangtua yang juga didasari oleh rasa takut akan Tuhan.
\end{abstract}

Kata Kunci: pendidikan kristen; keluarga; covid-19 


\section{Pendahuluan}

Dalam disiplin ilmu Pendidikan Kristen, orangtua memiliki peranan penting dalam mendidik anak. Orangtua memiliki kewajiban yang tidak dapat dihindari, yaitu memenuhi kebutuhan rohani dan jasmani sehingga anak tersebut tumbuh dengan normal, sehat dan cerdas. Keluarga adalah Lembaga pertama yang ditetapkan Allah dibumi. Allah mendirikan keluarga agar anak belajar dari orangtua. Sebelum membentuk jemaat dan pemerintah, Allah menabiskan pernikahan dan keluarga sebagai bangunan dasar masyarakat. Tidak ada tempat yang lebih baik dan penting untuk menumbuhkan iman, dan menaburkan nilai-nilai kristiani selain keluarga. ${ }^{1}$ Keluarga sebagai pendidik utama dimana keluarga meletakkan dasar spiritual iman Kristen dan moral, ${ }^{2}$ dapat juga disebut sebagai sebuah institusi pendidikan yang utama dan bersifat kodrati. ${ }^{3}$ Pada kenyataannya masih banyak orangtua yang tidak menyadari bahwa pertumbuhan kerohaian anak sangat dipengaruhi oleh orangtua, baik buruknya kerohanian anak sangat dipengaruhi oleh bagaimana pendidikan Kristen diterapkan didalam keluarga.

Melihat situasi sekarang ini yaitu situasi pandemi covid-19, dimana himbauan pemerintah untuk mengurangi aktifitas di luar rumah seolah memaksa masyarakat untuk melakukan aktifitas yang biasanya dilakukan di luar rumah harus dilakukan di dalam rumah seperti bekerja, beribadah dan belajar. Pandemi covid-19 sangat mempengaruhi sektor perekonomian masyarakat, banyak buruh atau karyawan yang terpaksa harus di PHK, pedagang-pedagang kuliner juga mengalami penurunan omset, bahkan tidak sedikit yang tutup. Bukan hanya sektor ekonomi saja, akan tetapi sektor pendidikan juga terdampak, anak-anak yang seharusnya datang ke sekolah dan berinteraksi dengan guru dan teman-temannya terpaksa harus berdiam di rumah dan melakukan pembelajaran dalam jaringan (daring), guru-guru terpaksa harus merumuskan kembali metode pembelajaran tatap muka menjadi metode pembelajaran daring. Demikian dengan keagamaan, khususnya agama Kristen. Dimana seharusnya umat kristiani beribadah dengan datang ke gereja terpaksa harus melakukan ibadah online, bagi para pelayan gereja dan pendeta mempersiapkan tata ibadah yang efektif untuk dinikmati jemaat pada saat ibadah online.

Pada sisi lain, pandemi covid-19 memiliki dampak yang baik bagi masyarakat, khususnya pada keluarga Kristen. Karena situasi seperti ini dapat dijadikan momen untuk membangun persekutuan di dalam rumah, pemulihan kasih mula-mula yang berakar pada dasar hubungan kasih suami-istri, lalu terhadap anak, juga memberikan kesempatan bagi orangtua dalam melaksanakan kewajibannya untuk mendidik anak

1 GP Harianto, Pendidikan Agama Kristen Dalam Alkitab Dan Dunia Pendidikan Masa Kini (Yogyakarta: ANDI, 2012).

2 Sudirman Lase, Pendidikan Agama Kristen Kepada Orang Dewasa (Medan: MITRA, 2011).

3 Syaiful Bahri Djamarah, Pola Asuh Orang Tua Dan Komunikasi Dalam Keluarga (Jakarta: Rineka Cipta, 2014). 
mereka kearah pertumbuhan rohani. ${ }^{4}$ Seperti apa yang dinyatakan oleh Turansky dan Miller yang berpendapat bahwa orangtua dalam keluarga memegang peranan yang sangat penting untuk mendidik anak khususnya Pendidikan Agama Kristen. Meskipun orangtua memiliki peran yang sangat penting dalam pertumbuhan kerohanian anak, tetapi orangtua harus menyadari bahwa Tuhanlah yang mengubah hati anak, orangtua hanya alat yang dipakai Tuhan dalam proses itu. ${ }^{5}$

Searah dengan pendapat di atas, teks Efesus 6: 1-4 menyatakan "dan kamu bapa-bapa, janganlah bangkitkan amarah di dalam hati anak-anakmu, tetapi didiklah mereka di dalam ajaran dan nasihat Tuhan." Pada ayat 1-3 nasihat Paulus diarahkan kepada anak-anak untuk taat kepada perintah orangtua. Lalu pada ayat 4 tepatnya di frasa terakhir sangat tegas dan lugas mengacu pada tugas dan kewajiban orangtua untuk mendidik anak-anak mereka dengan ajaran dan nasihat Tuhan. Artinya teks Efesus 6: 1-4 menjadi sangat penting untuk dipahami secara mendalam pemaknaannya agar diterapkan oleh para orangtua, apalagi berkaitan pada situasi pandemi Covid-19 dimana anak-anak sedang membutuhkan perhatian dan bimbingan orangtua.

Penjabaran mengenai latar permasalahan tersebut di atas, maka yang menjadi rumusan masalah dalam penelitian ini adalah bagaimana pendidikan Kristen dalam keluarga menurut Efesus 6: 1-4 dan bagaimana implikasi pendidikan Kristen menurut Efesus 6: 1-4 pada masa pandemi covid-19.

\section{Metode Penelitian}

Jenis penelitian ini adalah penelitian deskriptif dengan menggunakan model atau paradigma interpretatif lebih tepatnya disebut metode deskriptif interpretatif, dengan melakukan tafsir terhadap teks Efesus 6:1-4. Metode ini bertujuan membangun kerangka teori yang melandasi penafsiran, serta membeberkan hasil analisis atas dasar temuan yang diklarifikasi dengan teori. 6 Pencarian makna tafsir atau teknik pengumpulan data melalui tinjauan literatur yang relevan dengan fokus penelitian, literatur yang dimaksud seperti buku-buku tafsir dan jurnal mengenai teks Efesus 6:1-4 dan beberapa commentary dari para ahli. Kemudian ditambah dengan literatur pendukung mengenai pendidikan Kristen dalam keluarga. Setelah itu, datadata tersebut disatukan menjadi sebuah sintesis, dan disusun secara sistematis untuk ditarik menjadi sebuah kesimpulan yang berupa implikasi.

${ }^{4}$ Yakub Hendrawan Parangin Angin, "Peran Keluarga Untuk Bertahan Dan Bertumbuh Dalam Menghadapi Tantangan Di Era Disrupsi Dan Pandemi Covid-19," Jurnal Teologi RAHMAT 6, no. 2 (2020), http://sttrem.co.id/e-journal/index.php/jtr/article/view/14.

${ }^{5}$ Scott Turansky Miller dan Joanne, Menjadi Orang Tua Kristen (Jakarta: Nafiri Gabriel, 2014).

6 Endraswara, S. Metodologi Kristik Sastra (Yogyakarta: Penerbit Ombak, 2013). 


\section{Hasil dan Pembahasan}

\section{Eksegesis Teks Efesus 6: 1-4}

Mengawali proses penafsiran dimulai dari analisis konteks pada Surat Efesus. Marxen menguraikan konteks umum dari Surat Efesus, ia menjelaskan bahwa secara bentuk surat ini mengambil pola tradisional, tetapi menyangkut isinya, bagianbagian itu berbeda dengan bagian-bagian yang sejajar dalam surat-surat lain; artinya, surat-surat ini tidak membahas hal-hal yang khusus. Ucapan syukur itu adalah pujian untuk karunia yang memungkinkan bahkan orang bukan Yahudi (bnd.2:11) diikutsertakan dalam penciptaan yang secara eskatologis telah diperbaharui. Doa syafaatnya adalahorang-orang Kristen harus lebih semakin mengerti, dengan hati yang terang, dan pengharapan besar yang menantikan mereka, karena kini mereka masuk dalam Kerajaan yang kepalanya adalah Kristus. Segala kuasa tunduk kepadanya, karena Ia dibangkitkan oleh Tuhan. ${ }^{7}$

Surat Efesus mengikuti pola umum surat menyurat yang memiliki salam pembuka dan salam penutup. Salam biasa yang dicantumkan dalam surat-surat helenistik digantikan dengan "kasih karunia dan damai sejahtera dari Allah, Bapa kita dan dari Tuhan Yesus Kristus menyertai kamu." Ini merupakan salam yang menjadi ciri salam Paulus dalam surat-suratnya yang lain. ${ }^{8}$ Sebenarnya kunci dari seluruh pemikiran dalam Surat Efesus adalah terkumpulnya segala sesuatu di dalam Yesus Kristus. Tanpa Kristus alam semesta hanya merupakan ketidaksatuan dan ketidakharmonisan; semuanya hanya akan menunjukkan kekacauan. Kuasa manusia telah merusak hubungan sosial yang seharusnya ada antara manusia dan binatang; manusia dipisahkan dari manusia; golongan dari golongan; bangsa dari bangsa; ideologi dari ideologi; orang bukan-Yahudi dari orang Yahudi. ${ }^{9}$

Konteks terdekat dari teks Efesus 6:1-4 adalah terletak pada pasal 5 yang sedikit-sebanyak mengandung tentang moralitas setempat pada saat itu. Paulus membandingkan hubungan antara Kristus dan Gereja, lalu akhirnya menunjukkan tugas-tugas anak-anak dan para hamba Tuhan. Paulus selanjutnya mengurai bagaimana hidup sebagai orang yang percaya harus berhati-hati, ia memerintah jemaat pada saat itu untuk dipenuhi dengan Roh Kudus dan ia menunjukkan kepada mereka dampak dari kepenuhan Roh Kudus yang mempengaruhi berbagai aspek kehidupan.

Sesudah Paulus memberikan nasihat mengenai kehidupan dan peribadahan jemaat pada saat itu, ia mengacu pada kehidupan keluarga yang dimana keduanya sangat memiliki keterkaitan yang erat. Tidak berarti apa yang apa yang diberitakan

7 William Marxsen, Pengantar Perjanjian Baru Pendekatan Kritis Terhadap Masalah-Masalahnya. (Jakarta: BPK Gunung Mulia, 2009).

8 Peter T. O’Brien, Surat Efesus (Surabaya: Penerbit Momentum, 2013).

${ }^{9}$ William Barclay, Pemahaman Alkitab Setiap Hari: Surat Galatia Dan Efesus (Jakarta: BPK Gunung Mulia, 2008). 
kepada mereka dalam ibadah harus mereka praktekan dalam keluarga mereka dan dalam masyarakat, tetapi mungkin saja kalau nasihat Paulus yang menyatakan "hendaklah kamu penuh dengan Roh" berlaku baik dalam ibadah, maupun dalam keluarga dan masyarakat. ${ }^{10}$

Berikut adalah uraian analisis gramatikal, sintaksis, dan semantik pada Efesus 6: 1 - 4: "Hai anak-anak, taatilah orang tuamu di dalam Tuhan, karena haruslah demikian." (Ef 6:1). Kata "anak-anak" pada ayat ini dalam bahasa Yunani disebut tókv (tekna). ${ }^{11}$ Pada lexicon yang berbeda kata ini memiliki sebutan lain yaitu teknaevangelias

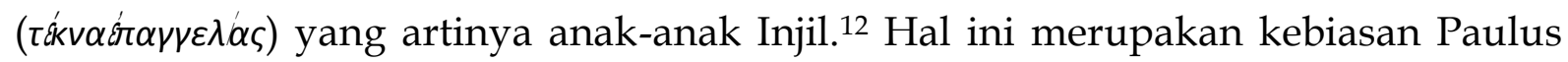
yang sering menyebut objek dari suratnya dengan kata-kata seperti "orang-orang kudus", "anak-anak cemar" untuk menyelaraskan dengan konten surat atau teologi dari Paulus sendiri. Artinya kata "anak-anak" yang dimaksud Paulus pada ayat ini ialah anak-anak dari orang yang percaya Kristus dengan kata lain anak-anak Kristen. Seperti halnya kepatuhan istri kepada suami, maka menjadi sebuah kewajiban seorang anak patuh kepada orangtua, hal ini merupakan kebajikan yang diakui secara umum pada masa itu, meskipun umum dalam konteks ini Paulus tetap memberikan penekanan dengan frasa 'di dalam Tuhan'. Patut dicermati mengapa Paulus dengan leluasa menyapa anak-anak, hal ini menunjukkan bahwa Paulus menganggap anak-anak sebagai anggota jemaat yang juga bertanggung jawab dalam pertumbuhan iman di dalam Kristus. ${ }^{13}$

Selanjutnya kata yang menarik untuk ditelaah lebih dalam adalah kata "taatilah", dalam bahasa Yunani disebut hupakouete. ${ }^{14}$ Ketaatan yang dimaksud Paulus adalah suatu keharusan, atau barangkali lebih baik, sesuatu yang benar, yang adil, sesuatu yang benar dan adil bagi Allah. Di dalam Kristus, Allah ini menyatakan kasih-Nya kepada orang tua, dan di dalam Dia, Ia memberikan kepada mereka suatu tempat yang terhormat. Itulah sebabnya Paulus

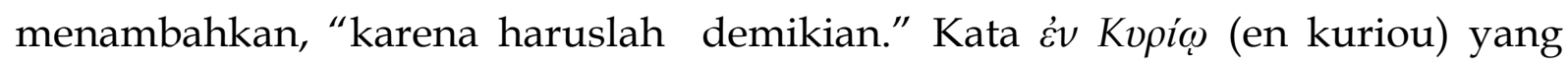
artinya "didalam Tuhan", merupakan penekanan terhadap frasa "taatilah orangtuamu." Paulus bermaksud memberikan nasihat yang tegas kepada anakanak bahwa taat kepada orangtua bukan untuk memenuhi standar sebagai anak, akan tetapi taat kepada orangtua merupakan sesuatu yang wajib dan hakiki

${ }^{10}$ Ch. J. L. Abineno, Tafsiran Alkitab Surat Efesus (Jakarta: BPK Gunung Mulia, 2003).

${ }_{11}$ Hasan Susanto, Perjanjian Baru Interlinier Yunani-Indonesia Dan Korkondansi Perjanjian Baru (PBIK) - Jilid 1 (Jakarta: Lembaga Alkitab Indonesia (LAI), 2006).

12 Joseph Henry Thayer, A Greek-English Lexicon Of The New Testament, 8th, Biblewo ed. (International Bible Translator (IBT), n.d.).

${ }^{13}$ John Barton and John Muddiman, The Oxford Bible Commentary (New York: Oxford University Press Inc, 2001). Jilid 1.

${ }^{14}$ Susanto, Perjanjian Baru Interlinier Yunani-Indonesia Dan Korkondansi Perjanjian Baru (PBIK) - 
dilakukan di dalam Tuhan. ${ }^{15}$ Ketaatan kepada orangtua berhubungan dengan kebiasaan baik yang mendukung umur panjang, hal ini akan menuntun seorang anak untuk menahan dan mnegatur nafsu liarnya; hal ini juga akan menuntun seorang anak untuk membentuk kebiasaan mengatur diri sendiri yang dimana pada suatu saat akan menyelematkannya dari jerat kejahatan dan godaan. ${ }^{16}$

Selanjutnya teks Efesus 6:2. Frasa "hormatilah ayahmu dan ibumu" menegaskan bahwa bagaimana seharusnya seorang anak memperlakukan orangtua. Mereka tidak hanya untuk dicintai, ditakuti dan untuk dihormati saja, mereka juga dapat diberikan koreksi ataupun masukan ketika melakukan sebuah pelanggaran yang seharusnya mereka akui. Kelemahan orangtua tidak harus ditutupi, tetapi meraka harus dihormati dalam pikiran, perekataan, dan gerak tubuh, mereka harus sangat dipikirkan dan dihargai, mereka juga harus diajak berbicara dengan sangat santun. ${ }^{17}$

Otoritas orangtua terhadap anak lebih ketat dibandingkan otoritas suami sebagai kepala terhadap isterinya. Seperti biasa, Paulus mendasarkan ajarannya dengan seksama. Ia memberikan tiga alasan mengapa anak-anak dalam rumah tangga Kristen wajib mentaati orang tuanya, yakni: kewajaran secara ilmiah, hukum, dan Injil. Sama seperti dari istri-istri (terhadap suami-suami mereka), demikian pula dari anakanak (terhadap orang tua mereka), Paulus menuntut, selain dari pada ketaatan. Ia mengandung juga aspek ketakutan, bukan ketakutan hamba atau budak, tetapi seperti yang telah didengar, ketakutan yang lahir dari ketakutan kepada Tuhan. ${ }^{18}$ Orang tua berhak atas penghormatan yang demikian. Hukum ini yaitu menghormati orang tua (Paulus sebut "suatu perintah yang penting, seperti yang nyata dari janji" yang berikut lih. ay. 3). Dari ayat 2 dan 3 itu berkesinambungan, dimana anak-anak ketika menghormati ayah dan ibunya itu adalah suatu perintah dan nyata dari janji yang sangat penting, supaya mereka menjadi berbahagia dan panjang umur.

Kemudian teks Efesus 6:3. Janji yang dimaksud Paulus pada ayat sebelumnya sedikit lain dari pada janji yang terdapat dalam hukum kelima: "supaya lanjut umurmu di tanah yang akan diberikan Tuhan, Allahmu, kepadamu” (Kel. 20:12). Anggota-anggota jemaat di Efesus adalah orang-orang yang berasal dari bangsa-bangsa kafir. Sesuai dengan itu, maka yang Paulus maksudkan di sini adalah di bumi bukanlah Tanah Kanaan, tetapi bumi atau dunia, di mana mereka diam. Menurut Gill dalam Keluaran 20:12 janji itu hanya ditujukan kepada bangsa Israel pada saat itu, dalam hal ini Paulus mengubah

15 https://biblehub.com/commentaries/pulpit/ephesians/6.htm

16 https://biblehub.com/commentaries/barnes/ephesians/6.htm

17 https://biblehub.com/commentaries/gill/ephesians/6.htm

18 John R.W. Stott, Seri Pemahaman Dan Penerapan Amanat Alkitab Masa Kini-Efesus (Jakarta: Yayasan Komunikasi Bina Kasih/OMF, 2003). 
bahasanya untuk menyesuaikan pada konteks jemaat Efesus. ${ }^{19}$

Teks Efesus 6:4. Jika pada penjelasan di atas anak-anak dinasihati untuk menaati dan menghormati orangtuanya, maka bagian ini lebih menekankan pada kewajiban bapak-bapak sebagai orangtua dan kepala keluarga, dimana hal itu selaras dengan konteks budaya jemaat Efesus, dalam budaya Yunani-Romawi dan dalam tulisan-tulisan Yahudi, bapak-bapak mempunyai tanggung jawab untuk mendidik anak-anak. ${ }^{20}$ Di dalam hukum Romawi yang berlaku bagi masyarakat pada waktu itu ditekankan tentang patria potestas (otoritas kepala rumah), di mana bapak-bapak diberikan kuasa tanpa batas atas anak-anak mereka, dan hukum ini mempunyai pengaruh yang sangat luas dalam budaya Helenistik pada waktu itu. Pada konteks yang berbeda anak merupakan sumber kebahagiaan yang luar biasa bagi setiap keluarga dan menjadi perekat keintiman suami sitri, tetapi anak juga berpontensi menjadi malapetaka dan sumber kekecewaan bagi keluarga itu sendiri. ${ }^{21}$

Dalam ayat ini sesudah Paulus selesai menasihati anak-anak, ia berkata kepada bapak-bapak: "Dan kamu, bapa-bapa janganlah bangkitkan amarahmu di hati anakanakmu, tetapi didiklah mereka di dalam ajaran dan nasihat Tuhan" (ay. 4). Dalam terjemahan Inggris KJV, yaitu: provote not (indignant) your children to wrath, dalam kalimat ini predikat "bangkitkan" memiliki makna yang negatif sehingga harus disertai dengan keterangan objek kalimat itu sendiri, "amarah didalam hati anakanakmu." Dalam bahasa Yunani frasa ini berbentuk "parorgizo" yang artinya "to irritate beyond measure" yang artinya "untuk membuat jengkel anak secara luar biasa," sehingga akan menghasilkan bibit kekerasan terhadap anak. ${ }^{22}$

Pertanyaan tentang mengapa ibu-ibu tidak turut disebut disini, padahal mereka juga adalah orang tua yang turut bertanggung jawab atas pendidikan anakanak mereka, tidak diketahui sebab yang sebenarnya. Mungkin karena Paulus menganggap bahwa bapak-bapak sebagai kepala rumah tangga (keluarga) yang memikul dan mewakili wibawa orang tua. ${ }^{23}$ Stott mengutip penjelasan Barclay yang menyatakan, Bapak Romawi memegang dan menerapkan kekuasaan mutlak atas keluarganya. Ia boleh sesukanya menjual anak-anaknya menjadi hamba, memaksa mereka bekerja di ladang bahkan dengan terbelenggu, menghukum mereka sampai pada hukuman mati karena kuasa menghukum ada padanya. ${ }^{24}$ Konteks tersebut tentu saja sangat berpengaruh pada cara pandang, bagaimana menyikapi pemberian

19 https:/ / biblehub.com/commentaries/gill/ephesians/6.htm

${ }^{20} \mathrm{O}^{\prime}$ Brien, Surat Efesus.

${ }^{21}$ E.B. Surbakti, Sudah Siapkah Menikah (Jakarta: Elex Media Komputindo, 2008).

${ }^{22}$ Elisa Elthon Tannu and Reymand Hutabarat, "ANALISIS TEOLOGIS PEMAHAMAN DAN

PENERAPAN ORANG TUA TERHADAP MAKNA 'JANGANLAH BANGKITKAN AMARAH DI DALAM HATI ANAK-ANAKMU’ BERDASARKAN EFESUS 6:4 DI GEREJA MASEHI ADVENT HARI KETUJUH JEMAAT PALEM SEMI DAN JEMAAT MAKARIOS KONFERENS DKI JAKARTA,” Jurnal Marturia 1 , no. 1 (2017).

${ }^{23}$ Abineno, Tafsiran Alkitab Surat Efesus.

24 Stott, Seri Pemahaman Dan Penerapan Amanat Alkitab Masa Kini-Efesus. 
didikan bagi anak-anak.

Hak mendidik yang jatuh pada seorang ayah merupakan sesuatu yang terkesan konvensional pada ayat ini. Seorang ayah memiliki otoritas hukum tunggal atas anakanaknya dan tanggung jawab utama untuk mendisiplinkan dan mengarahkan (paideia), akan tetapi pada konteks yang sama jika kekuasaan itu ditangani secara tidak bijaksana dapat dengan mudah memprovokasi atau mengarahkan anak-anak pada kebencian yang merusak tatnan rumah tangga dan keluarga, maka dari itu penekanan kata 'Tuhan' menjadi patokan bagaimana seorang ayah memberikan arahan atau nasihat kepada anak mereka. ${ }^{25}$

Paulus memahami bahwa amarah dapat membawa seseorang kepada dosa dan kepada kuasa Iblis (4:26). Jelas dengan amarah dan segala sesuatu yang berhubungan dengan hal itu, orang dapat jatuh ke dalam perbuatan fitnah (bnd. 4:31), yang memisahkannya dari persekutuan dengan Allah. Terutama untuk anak-anak, hal itu sangat berbahaya. Seorang ayah yang menyebabkan hati anaknya menjadi panas atau marah, sadar atau tidak sadar sedang memimpin mereka kepada pemberontakan melawannya. Hal itu bisa juga berdampak pada pemberontakan melawan Allah sebagai Bapa. Mengapa hal itu terjadi, tidak dikatakan oleh Paulus dengan jelas. Bukankah sikap, perkataan, perbuatan, tindakan, dan lain sebagainya dari orang tua, terutama bapak-bapak, sangat berpengaruh pada diri seorang anak? Itulah sebabnya teladan yang tidak baik perlu dihindarkan. Paulus juga menasihatkan mereka secara positif supaya mereka mendidik anak-anak mereka di dalam ajaran dan nasihat Tuhan. ${ }^{26}$

Pendidikan keras yang biasanya diterapkan pada waktu itu seringkali membuat anak-anak menyimpan amarah di dalam hati mereka. Amarah ini jelas akan menghancurkan kehidupan anak-anak tersebut, seperti yang diperingatkan oleh Paulus dalam Efesus 4:26-31, di mana Iblis akan mengambil keuntungan dari amarah yang berlarut-larut. Karena itu Paulus menentang praktik pendidikan yang keras dan sewenang-wenang. Selain perintah yang bersifat negatif, Paulus melanjutkan nasihatnya untuk bapak-bapak agar mendidik anak-anak mereka. Kata 'tetapi' disini menunjukan adanya suatu kontras dari yang tidak seharusnya dilakukan menjadi apa yang seharusnya dilakukan. Hal ini diperkuat dengan perintah yang harus secara

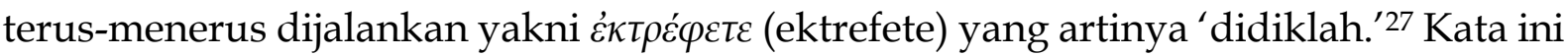
mempunyai arti mengasuh dan mendidik anak-anak menuju kedewasaan. Baik dengan memenuhi kebutuhan fisik mereka maupun kebutuhan psikis mereka. Didikan inilah yang akan menghindarkan bangkitnya amarah di dalam diri anakanak, karena melalui didikanlah anak-anak mewarisi gaya hidup kristiani.

25 Barton and Muddiman, The Oxford Bible Commentary.

${ }^{26} \mathrm{O}$ 'Brien, Surat Efesus.

27 Susanto, Perjanjian Baru Interlinier Yunani-Indonesia Dan Korkondansi Perjanjian Baru (PBIK) Jilid 1. 


\section{Pendidikan Kristen Dalam Keluarga Menurut Efesus 6: 1-4}

Pada umumnya pendidikan Kristen merupakan produk dari para tokoh Alkitab yang mengambil peranan penting dalam pengajaran mengenai Tuhan pada masa itu dan yang menekankan bahwa pentingnya pendidikan Kristen dalam dimensi keluarga. Mengapa demikian, hal ini dikarenakan ruang lingkup pengajaran atau pendidikan mengenai Tuhan pada saat itu dipengaruhi oleh budaya Israel kuno yang dikenal dengan istilah "tradisi lisan." Lebih tepatnya dimulai sejak penggilan para bapak leluhur seperti Abraham, Ishak dan Yakub, yang diberi tugas menjadi penyambung perkataan Allah untuk mendidik umat Israel.

Penjabaran eksegesis teks Efesus 6:1-4, dapat ditarik sebuah makna bahwa pendidikan Kristen dalam keluarga yang dimaksud dalam Efesus 6:1-4 dasarnya adalah takut akan Tuhan atau melakukan perintah Tuhan, seorang anak melakukan kewajibannya untuk menghormati orangtua dasarnya adalah takut akan Tuhan atau melakukan perintah Tuhan. Demikian juga dengan orang tua melakukan kewajibannya mendidik anak yang dasarnya juga takut akan Tuhan atau melakukan perintah Tuhan. Tetapi semuanya itu akan terjalin harmonis, jika semuanya diawali oleh orangtua yang dengan benar melakukan pendidikan Kristen kepada anak, sehingga seorang anak menghormati orangutanya merupakan dampak dari pendidikan dari orangtua, terkhusus seorang ayah yang menjadi pemimpin keluarga.

Di dalam hukum Romawi yang berlaku bagi masyarakat pada waktu itu ditekankan tentang patria potestas (otoritas kepala rumah), di mana bapak-bapak diberikan kuasa tanpa batas atas anak-anak mereka, dan hukum ini mempunyai pengaruh yang sangat luas dalam budaya Helenistik pada waktu itu. Hak mendidik yang jatuh pada seorang ayah merupakan sesuatu yang terkesan konvensional pada ayat ini. Seorang ayah memiliki otoritas hukum tunggal atas anak-anaknya dan tanggung jawab utama untuk mendisiplinkan dan mengarahkan (paideia), akan tetapi pada konteks yang sama jika kekuasaan itu ditangani secara tidak bijaksana dapat dengan mudah memprovokasi atau mengarahkan anak-anak pada kebencian yang merusak tatnan rumah tangga dan keluarga, maka dari itu penekanan kata 'Tuhan' menjadi patokan bagaimana seorang ayah memberikan arahan atau nasihat kepada anak mereka. ${ }^{28} \mathrm{Hal}$ ini masih sangat relevan, maka dari itu sangat penting bagi seorang ayah untuk terlebihi dahulu ada pada konteks "di dalam Tuhan" seperti yang ditekankan Paulus pada ayat ini. Artinya, seorang ayah sudah sepatutnya memiliki rasa takut akan Tuhan dan melakukan perintah Tuhan terlebih dahulu, sehingga hal itu akan berdampak kepada anak yang juga akan memiliki rasa takut akan Tuhan dan

28 Barton and Muddiman, The Oxford Bible Commentary. 
akan menghormati orangtuanya atas dasar melakukan perintah Tuhan.

\section{Implikasi Pendidikan Kristen Dalam Keluarga Menurut Efesus 6: 4 di Masa Pandemi Covid-19}

Bagian ini akan memaparkan bagaimana pentingnya pendidikan Kristen dalam keluarga menurut Efesus 6: 1-4 pada masa pandemi covid-19. Pandemi covid-19 ada di Indonesia mulai bulan Maret 2020 walaupun terdengar kabar perama kalinya pada tahun 2019. Sebagai upaya mengurai tingkat penyebaran virus covid-19, pemerintah Indonesia menghimbau agar masyarakat mengurangi aktifitas diluar rumah dengan melakukan kegiatan seperti bekerja, belajar dan beribadah di rumah saja. Situasi seperti ini membuat masyarakat resah, karena sulit untuk tidak keluar rumah, apalagi bagi masyarakat yang mencari nafkah dengan upah harian. Bagi anak-anak sekolah juga sulit beradaptasi untuk menerima materi pembelajaran melalui daring (dalam jaringan). Bagi pemeluk agama pun demikian, terkhusus umat Kristen di Indonesia harus dengan rela beribadah di rumah dengan arahan dari pendeta melalui media online seperti youtube, Instagram dan lainnya.

Pendidikan Agama Kristen berperan penting untuk mendorong anak-anak untuk menyatakan imannya dalam lingkungan yang terkecil dari keluarga sampai pada lingkungan yang besar. Terutama pendidikan dalam kerangka berpikir kritis menjadi sangat penting bagi manusia dalam menghadapi kesulitan dan ketertindasan akan ancaman pandemi covid-19.29 Sikap kritis dan sikap iman yang benar dalam menghadapi covid-19 sangat diperlukan. Sikap menyatakan iman seperti membawa kabar kesukaan dan pengharapan di dalam Tuhan yang membuat orang percaya baik dalam keluarga untuk teguh berdiri dan tidak kuatir maupun cemas menghadapi Covid-19. Karena Keluargalah sesungguhnya yang menjadi unit terkecil yang paling efektif mencegah, memperlengkapi, dan mengampanyekan pola hidup keluarga yang baik, bertumbuh, dan menjadi berkat di tengah masyarakat saat ini. ${ }^{30}$

Dibalik semua dampak negatif karena pandemi covid-19, ada hal positif yang harus disyukuri jika orang-orang Kristen khususnya dapat memaknai pandemi ini sebagai sebuah kesempatan untuk membangun kualitas dengan keluarga. Selama ini mungkin hubungan suami dengan istri tidak baik dikarenakan suami sibuk bekerja dan istri sibuk megurus semua perihal rumah dan anak-anak, karena di rumah saja serta didampingi dengan persekutuan seperti berdoa berdoa bersama dan beribadah

${ }^{29}$ Hasudungan Sidabutar and Rinto Hasiholan Hutapea, "Sikap Kritis Manusia Di Masa Pandemi Covid-19 Dalam Perspektif Filsafat Pendidikan Human Critical Attitude In The Covid-19

Pandemic In The Education Philosophy Perspective," Widyadewata: Jurnal Balai Diklat Keagamaan Dempasar 3 (2020): 12-21, https://widyadewata.kemenag.go.id/index.php/widyadewata/article/view/6.

30 Albert Saragih Johanes Waldes Hasugian, "Model Asuhan Keluarga Kristen Di Masa Pandemi Covid-19," Jurnal Teruna Bhakti 3, no. 1 (2020), http://stakterunabhakti.ac.id/ejournal/index.php/teruna/article/view/56. 
bersama dapat membangun kembali hubungan itu agar menjadi harmonis. Di zaman modern ini banyak orang tua gagal dalam membangun komunikasi kepada anakanaknya. Sejaknya adanya handphone, orang tua jarang berkomunikasi dengan anakanaknya, orang tua lebih sibuk main handphone demi untuk membangun relasi ketimbang mengajak anak-anak untuk berkomunikasi. Sejatinya membangun komunikasi dengan anak sengatah penting, karena hal itu dapat mempererat hubungan emosional antara orang tua dengan anak. ${ }^{31}$

Dalam konteks yang berbeda mungkin saja hubungan orangtua dengan anak tidak baik dikarenakan orangtua memiliki dunianya sendiri dan anak-anak pun demikian. Masa pandemi seperti ini harus dijadikan momen oleh orangtua untuk membangun kembali hubungan komunikasi yang baik dengan anak-anak. Situasi ini juga menjadi kesempatan bagi orangtua untuk dapat menjadi mentor dan pembimbing kerohanian anak-anak.

Banyak hal yang lain dalam keluarga yang mungkin hilang sebelum adanya pandemi covid-19, akan tetapi menjadi sebuah kesempatan yang baik bagi orangtua untuk membangun kembali kualitas itu dengan mengambil peran sebagai pembimbing rohani bagi anak-anak, inilah yang disebut implementasi pendidikan Kristen dalam keluarga. O'Brien menekankan bahwa Surat Efesus sangat penting untuk mendukung hal ini. Surat Efesus membuat beberapa penegasan teologis penting tentang umat Allah. Surat ini memperkenalkan serangkaian gambaran yang sangat penting tentang gereja, termasuk istilah-istilah seperti tubuh, bangunan, bait, dalam Kristus, pengantin, manusia baru, keluarga, dan pernikahan. Maka tidak heran kalau mereka kemudian melihat banyak klaim yang mengatakan bahwa tulisan Perjanjian Baru ini berisi tulisan tentang "ekklesiologi yang paling tinggi dari semuanya." Rujukan-rujukan yang dimaksud dan pengajaran khusus yang dihadirkan melalui gambaran-gambaran yang beragam dan memiliki jangkauan luas ini memiliki makna yang penting. Sedangkan implikasi-implikasi dari semua itu memberikan tantangan besar terhadap semua hal yang bersifat dangkal, duniawi, berpusat pada diri sendiri, dan individualistik dalam jemaat-jemaat pada masa kini. ${ }^{32}$

Keluarga merupakan lingkungan yang terutama melakukan pembentukan sosial anak untuk menentukan tujuan seorang anak dan tempat tumbuh kembang. Pendidikan Kristen dalam keluarga sangat penting, agar setiap orangtua mengerti bagaimana memperlakukan dan cara pendampingan kepada anak-anak. Tujuan pendidikan Kristen menurut Luther yaitu melibatkan semua warga jemaat, khususnya kaum muda dalam rangka belajar teratur dan tertib agar semakin sadar akan dosadosanya. ${ }^{33}$ Pendidikan Kristen dalam keluarga bertujuan untuk mengalami proses

31 Talizaro Tafonao, "Peran Pendidikan Agama Kristen Dalam Keluarga Terhadap Perilaku Anak," Edudikara: Jurnal Pendidikan dan Pembelajaran 3, no. 2 (2018).

32 O’Brien, Surat Efesus.

33 Robert R. Boehlke, Sejarah Perkembangan Pikiran Dan Praktek Pendidikan Agama Kristen: Dari 
pertumbuhan sebagai pribadi dewasa dalam segala aspek, mampu mengidentifikasi berbagai pergumulan dalam keluarga serta kaitannya dengan pengaruh modernisasi, mampu menjelaskan makna kebersamaan dengan orang lain tanpa harus kehilangan identitasnya sebagai orang Kristen yang percaya kepada Yesus Kristus, mampu mewujudkan nilai-nilai Kristiani dalam menghadapi gaya hidup modern, serta mampu mengkritisi perkembangan budaya dan Iptek. ${ }^{34}$ Berdasarkan pada prinsipprinsip ini boleh dikatakan bahwa keluarga harus berfungsi sebagai tempat untuk dipercaya dan saling berbagi beban masalah, mendiskusikan pokok-pokok masalah, mematangkan segi emosional, mendapatkan dukungan spiritual. ${ }^{35}$ Artinya keluarga harus mampu mendengar dan menyimpan kepercayaan serta mengarahkan memberikan petunjuk apa yang harus dilakukan ketika anak-anak mengalami masalah, keluarga memberikan perhatian dan mendengar secara serius karena apa yang menjadi beban seorang anak merupakan beban keluarga yang harus diselesaikan secara bersama-sama, memberikan kekuatan untuk menghadapi setiap masalah dengan mengenalkan Tuhan yang sanggup mengatasi setiap persoalan tersebut.

Suharti menyatakan pendidikan Kristen dalam keluarga sangat penting diterapkan oleh orang tua di zaman sekarang. Salah satu peran Pendidikan Kristen dalam keluarga saat ini adalah mengupayakan kerjasama orang tua ayah dan ibu dalam mendidik anak serta menciptakan keharmonisan dalam keluarga. Peranan orang tua dalam mengasuh anak-anak sangatlah penting, bukan hanya anak belajar dan mengalami pertumbuhan di dalam keluarga, tetapi seluruh anggota keluarga dapat saling belajar dari yang lain melalui interaksi satu sama lain. Ketika orang tua menjalankan peranan pendidikannya terhadap anak, ia sendiri juga belajar untuk bertumbuh dalam iman didalam dimensi tindakan, sikap bahkan pengetahuan. ${ }^{36}$ Sejatinya pendidikan agama Kristen adalah sebuah usaha untuk mendidik serta mengajar berdasarkan firman Allah kepada semua orang yang membutuhkan bimbingan yang disesuaikan dengan kebutuhan hidup agar dapat memahami dan menghayati nilai-nilai kristiani serta mengaplikasikannya dalam kehidupan baik melalui kata-kata, sikap hidup yang mencerminkan Kristus. ${ }^{37}$

Yohanes Amos Comenius Sampai Perkembangan PAK Di Indonesia (Jakarta: BPK Gunung Mulia, 2009).

34 Janse Belandina Non Seraano, Profesionalisme Guru Dan Bingkai Materi Pendidikan Agama Kristen SD, SMP, SMA (Bandung: Bina Media Informasi, 2009). 2013).

${ }^{35}$ E. G. dan I. H. Enklaar Homrighausen, Pendidikan Agama Kristen (Jakarta: BPK Gunung Mulia,

${ }^{36}$ R. I. C. Suharti, Cara Mendidik Anak Dalam Keluarga Kristen (Jakarta: Bhratara Karya Aksara, 1990).

37 Yonatan Alex Arifianto, "Pentingnya Pendidikan Kristen Dalam Membangun Kerohanian Keluarga Di Masa Pandemi Covid-19," REGULA FIDEI: Jurnal Pendidikan Agama Kristen 5, no. 2 (2020), http://christianeducation.id/e-journal/index.php/regulafidei/article/view/52. 


\section{Implikasi}

Dari penjabaran mengenai pendidikan Kristen menurut Efesus 6:1-4 dan dari penjelasan mengenai situasi yang di alami keluarga Kristen pada masa pandemi covid-19, maka yang merupakan implikasi pendidikan Kristen dalam keluarga menurut Efesus 6:1-4 di masa pandemi covid-19, adalah: membangun kualitas keharmonisan hubungan antara orangtua dan anak adalah langkah selanjutnya setelah hubungan antara suami dan istri terjalin harmonis. Dalam hal ini orangtua harus berkomitmen membagi waktu untuk berinteraksi dan melakukan tugas mereka untuk terlibat dalam mendidik anak. Masa pandemi Covid-19 seperti ini merupakan momen yang tepat bagi orangtua untuk meningkatkan kualitas komunikasi kepada anak dan mendidik mereka.

Meningkatkan kualitas peran orangtua terhadap pertumbuhan rohani anak. Seperti apa yang telah dijabarkan pada eksegesis Efesus 6:1-4, pertumbuhan rohani anak sudah merupakan tanggung jawab dari orangtua. Anak-anak akan menjadi patuh kepada orangtua mereka ketika mereka bertumbuh secara rohani, karena sepanjang teks Efesus 6:1-4 penekanan frasa 'di dalam Tuhan' menjadi kualifikasi penting dalam hal anak mematuhi orangtua. Demikian juga halnya pada konteks orangtua, khususnya peran ayah sebagai kepala keluarga dalam mendidik anak, penekanan kata 'Tuhan' merupakan kualifikasi dari bagaimana seharusnya seorang ayah mendidik dan mengarahkan anaknya sehingga mengalami pertumbuhan rohani yang signifikan. Inilah tanggung jawab utama dan seharusnya dari bapak-bapak. Seperti yang ditekankan oleh Alkitab, yakni melalui penggunaan kata: oinatépєs - hoi pateres atau bapak-bapak. Begitu pentingnya posisi seorang laki- laki sebagai seorang kepala keluarga. Pada saat ini, banyak juga para ibu yang menjadi kepala keluarga, dikarenakan kehilangan suami atau ditinggalkan suami. Pada umumnya ayat ini ditunjukan kepada para keluarga. Para kepala keluarga mempunyai tanggung jawab yang besar dalam pendidikan anak- anak mereka. Posisi kepala keluarga sangatlah penting, karena sebagai kepala keluarga ia akan memberikan contoh kepada seisi rumahnya. Gaya hidup dan kerohanian kepala keluarga akan sangat mempengaruhi gaya hidup dan kerohanian seluruh anggota keluarga. Pada masa pandemi seperti dapat dimanfaatkan bagi para ayah untuk melakukan kewajiban yang seharusnya mereka lakukan dari dulu.

\section{Kesimpulan}

Keluarga merupakan lingkungan yang terutama melakukan pembentukan sosial anak untuk menentukan tujuan seorang anak dan tempat tumbuh kembangnya. Pendidikan Kristen dalam keluarga sangat penting, agar setiap orangtua mengerti bagaimana memperlakukan dan cara pendampingan kepada anak-anak. Menurut Efesus 6:1- 4, beban ini lebih difokuskan pada peran ayah sebagai pemimpin keluarga, kendatipun demikian tidak menutup kemungkinan peran ibu juga sangat penting 
untuk melengkapi tugas dan tanggungjawab ini. Seperti yang telah dijabarkan, seorang anak yang melakukan tugas dan tanggungjawab untuk menghormati orangtuanya berdasarkan rasa takut akan Tuhan merupakan dampak dari peran orangtua untuk mengarahkan dan mendidik anak tersebut berdasarkan rasa takut akan Tuhan, artinya rasa takut akan Tuhan harus diawali dan dimiliki oleh orangtua terlebih dahulu sebelum menanamkan hal itu kepada anak.

Masa pendemi covid-19 seperti ini menjadi momen yang tepat untuk menerapkan pendidikan Kristen dalam keluarga, jika ada orangtua yang belum menerapkannya. Juga dapat dijadikan momen untuk membangun kembali, jika ada orangtua yang lalai karena terlalu sibuk dengan pekerjaannya, bahkan dapat dijadikan momen untuk meningkatkan kualitas pendidikan Kristen dalam keluarga, jika selama ini sebelum pandemi hal itu sempat berjalan dengan datar atau biasa-biasa saja. Sehingga hubungan antara orangtua dan anak akan terjalin harmonis.

\section{Rujukan}

Abineno, Ch. J. L. Tafsiran Alkitab Surat Efesus. Jakarta: BPK Gunung Mulia, 2003. Angin, Yakub Hendrawan Parangin. “Peran Keluarga Untuk Bertahan Dan Bertumbuh Dalam Menghadapi Tantangan Di Era Disrupsi Dan Pandemi Covid-19." Jurnal Teologi RAHMAT 6, no. 2 (2020). http:/ / sttrem.co.id/ejournal/index.php/jtr/article/view/14.

Arifianto, Yonatan Alex. "Pentingnya Pendidikan Kristen Dalam Membangun Kerohanian Keluarga Di Masa Pandemi Covid-19." REGULA FIDEI: Jurnal Pendidikan Agama Kristen 5, no. 2 (2020). http:/ / christianeducation.id/ejournal/index.php/regulafidei/article/view/52.

Barclay, William. Pemahaman Alkitab Setiap Hari: Surat Galatia Dan Efesus. Jakarta: BPK Gunung Mulia, 2008.

Barton, John, and John Muddiman. The Oxford Bible Commentary. New York: Oxford University Press Inc, 2001.

Boehlke, Robert R. Sejarah Perkembangan Pikiran Dan Praktek Pendidikan Agama Kristen: Dari Yohanes Amos Comenius Sampai Perkembangan PAK Di Indonesia. Jakarta: BPK Gunung Mulia, 2009.

Djamarah, Syaiful Bahri. Pola Asuh Orang Tua Dan Komunikasi Dalam Keluarga. Jakarta: Rineka Cipta, 2014.

Endraswara, S. Metodologi Kritik Sastra. Yogyakarta: Penerbit Ombak, 2013.

Harianto, GP. Pendidikan Agama Kristen Dalam Alkitab Dan Dunia Pendidikan Masa Kini. Yogyakarta: ANDI, 2012.

Hasugian, Albert Saragih Johanes Waldes. “Model Asuhan Keluarga Kristen Di Masa Pandemi Covid-19." Jurnal Teruna Bhakti 3, no. 1 (2020). http://stakterunabhakti.ac.id/e-journal/index.php/teruna/article/view/56.

Homrighausen, E. G. dan I. H. Enklaar. Pendidikan Agama Kristen. Jakarta: BPK Gunung Mulia, 2013.

Lase, Sudirman. Pendidikan Agama Kristen Kepada Orang Dewasa. Medan: MITRA, 2011. 
Marxsen, William. Pengantar Perjanjian Baru Pendekatan Kritis Terhadap MasalahMasalahnya. Jakarta: BPK Gunung Mulia, 2009.

Miller, Scott Turansky, and Joanne. Menjadi Orang Tua Kristen. Jakarta: Nafiri Gabriel, 2014.

O’Brien, Peter T. Surat Efesus. Surabaya: Penerbit Momentum, 2013.

Seraano, Janse Belandina Non. Profesionalisme Guru Dan Bingkai Materi Pendidikan Agama Kristen SD, SMP, SMA. Bandung: Bina Media Informasi, 2009.

Sidabutar, Hasudungan, and Rinto Hasiholan Hutapea. "Sikap Kritis Manusia Di Masa Pandemi Covid-19 Dalam Perspektif Filsafat Pendidikan Human Critical Attitude In The Covid-19 Pandemic In The Education Philosophy

Perspective." Widyadewata: Jurnal Balai Diklat Keagamaan Dempasar 3 (2020): 1221.

https://widyadewata.kemenag.go.id/index.php/widyadewata/article/view /6.

Stott, John R.W. Seri Pemahaman Dan Penerapan Amanat Alkitab Masa Kini-Efesus. Jakarta: Yayasan Komunikasi Bina Kasih/OMF, 2003.

Suharti, R. I. C. Cara Mendidik Anak Dalam Keluarga Kristen. Jakarta: Bhratara Karya Aksara, 1990.

Susanto, Hasan. Perjanjian Baru Interlinier Yunani-Indonesia Dan Korkondansi Perjanjian Baru (PBIK) - Jilid 1. Jakarta: Lembaga Alkitab Indonesia (LAI), 2006.

Tafonao, Talizaro. “Peran Pendidikan Agama Kristen Dalam Keluarga Terhadap Perilaku Anak." Edudikara: Jurnal Pendidikan dan Pembelajaran 3, no. 2 (2018).

Tannu, Elisa Elthon, and Reymand Hutabarat. "ANALISIS TEOLOGIS PEMAHAMAN DAN PENERAPAN ORANG TUA TERHADAP MAKNA ‘JANGANLAH BANGKITKAN AMARAH DI DALAM HATI ANAKANAKMU' BERDASARKAN EFESUS 6:4 DI GEREJA MASEHI ADVENT HARI KETUJUH JEMAAT PALEM SEMI DAN JEMAAT MAKARIOS KONFERENS DKI JAKARTA." Jurnal Marturia 1, no. 1 (2017).

Thayer, Joseph Henry. A Greek-English Lexicon Of The New Testament. 8th, Biblewo ed. International Bible Translator (IBT), n.d.

Turansky, Scott dan Joanne Miller. Menjadi Orang Tua Kristen. Jakarta: Nafiri Gabriel, 2014. 